\title{
The Impact of Methods of Presenting Cash Flow Statement on Loan Decision: Evidence from Vietnam
}

\author{
Dung Duc NGUYEN ${ }^{1}$
}

Received: June 02, 2020 Revised: June 28, 2020 Accepted: July 09, 2020

\begin{abstract}
The paper aims to investigate the impact of presenting statements of cash flow using the direct method and the indirect method on loan decision by credit officers at Vietnamese banks. The data was collected from 150 credit officers of commercial banks in Vietnam based on the questionnaire about making loan decision when the cash flow statement is presented in different methods, namely, direct and indirect methods. This research uses T-tests to check whether using the direct or indirect method affects the accurate calculation of loan criteria, affects the loan decision by credit officers, and compare these two methods in the aspects of information provision. The research has pointed out that: 1) the direct method helps the calculation of indicators related to loans more accurately; 2) credit officers say that, while the direct method of presenting cash flow statement provides clearer information, the use of either the direct method or the indirect method does not affect the banks' loan decision. Since then, the author recommends that cash flow statements should be provided with information in a direct method to present the information needed for loan decision more accurately so as to improve the quality of cash flow statement.
\end{abstract}

Keywords: Cash Flow Statement, Direct Method, Indirect Method, Loan Decision, Commercial Bank

JEL Classification Code: G30, M40, M41, D81, G11, G41

\section{Introduction}

In a cash flow statement, much attention is paid to the cash flow from operating activities like the net profit from operating activities from the income statement. High cash flow from operating activities demonstrates the ability of businesses to generate money, thereby ensuring the ability to pay liabilities and expand investment activities. Therefore, the method of presenting cash flow statement is also an issue mentioned quite a lot in the studies. Currently, there are two methods of presenting cash flow statement for companies: the direct method and the indirect method. These two methods only affect the cash flow from operating activities. When adopting the method of presenting cash

${ }^{1}$ First Author and Corresponding Author. Lecturer, School of Accounting and Auditing, National Economics University, Vietnam [Postal Address: 207 Giai Phong Road, Dong Tam Ward, Hai Ba Trung District, Hanoi, 113068, Vietnam] Email: dungnd2141@gmail.com

(c) Copyright: The Author(s)

This is an Open Access article distributed under the terms of the Creative Commons Attribution Non-Commercial License (http://Creativecommons.org/licenses/by-nc/4.0/) which permits unrestricted noncommercial use, distribution, and reproduction in any medium, provided the original work is properly cited. flow statement based on SFAS 95 of United States, the number of votes for both methods was approximately the same. The support ratio for the direct and indirect methods was $4: 3$. This proves that the debate was quite lively to support either method. Both IASB and FASB allow firms to use both direct and indirect methods of presenting cash flow statement. Although the direct method is more encouraged, most firms use the indirect method when presenting cash flow statement, still quite a few firms use the direct method. This happens in all countries where firms are allowed to choose to make cash flow statement in direct method or indirect method.

This research examines whether the method of presenting cash flow statement in direct method and indirect method influences the decision of the credit institutions according to the opinion of the credit officers. In short, do the methods of presenting cash follow statements affect the accurate calculation of loan information by credit officers and the decision of information users. The sections in this essay include introduction, literature review, research design, discussion of results and policy implications related to the research. 


\section{Literature Review}

\subsection{Comparison of Information Provision on Cash Flow Statements}

Under the direct method, cash inflows and outflows from operating activities are determined and presented in the cash flow statement by directly analyzing and aggregating revenues and expenditures according to amount of revenue and expenditure from general and detail accounting books of the firms. Under the indirect method, cash inflows and outflows from operating activities are calculated and determined firstly by adjusting the pre-tax profit of the business from the influence of the non-cash items, changes in the period of inventories, receivables, payables from operating activities and amounts that affect cash flows from investing activities.

According to Wallace, Choudhury and Pendlebury (1997), the purpose of information on cash flows from operating activities should provide information on the following factors related to cash flow from operating activities:

(a) Nature of origin of cash flows from operating activities;

(b) Information on components of cash flows from operating activities;

(c) Information on interest payments;

(d) Information of income tax paid;

(e) Information about dividends.

Since then, many scholars support presenting cash flow statement in the direct method. They recognized that information in cash flow statements will influence user decision, and the method of presenting cash flow statement is one of the factors influencing decision of investors to the stock market. The direct method will help readers better understand and apply information more flexibly. According to Miller et al. (1996), empirical investigations have found a significant difference between the expectations and the reality of cash flows; the findings and conclusions indicate that the results from the indirect method of predicting cash flow are not reliable. Therefore, these authors recommend that firms must use the direct method when presenting cash flow statement.

Building on this point of view, Miller and Bahnson (2002) recommend that presenting cash flow statement in the direct method provides more complete and useful information to investors, creditors or business managers. The indirect method of presenting cash flow statement does not help users to see how the cash flow of the business in the firms operates, but simply the adjustment of the criteria from the profit of the business. According to Broome (2004), adjusting the profitability target of cash flow from operating activities required by the indirect method may cause confusion for users. If users cannot understand the details of the adjustment, it will not help readers of the financial statements to see the suitability or difference between profit before tax and cash flow from operating activities. The direct method should be prioritized for several reasons. First, there is currently no standardization in the format of cash flow statements among firms. Second, the connection of profits and operating cash flow varies in practice especially outside the United States. The profit before tax target, which has not created the trust of users, is the first one used for adjustment.

Orpurt and Zang (2009) provide evidence that the components of a cash flow statement using the direct method cannot be correctly converted from the indirect method. More specifically, Farshadfar and Monem (2013), based on data from 348 businesses in Australia, provided additional evidence that operating cash flow carried out in the direct method helped increase the ability to predict future cash flows. Research shows that money received from customers, and payments to suppliers and employees are complementary to each other in increasing the overall predictability of cash flow components. The authors also work on a model that explains how the cash flow in the direct method affects the stock prices of firms listed on the stock exchange, which cannot be explained in the indirect method of presenting cash flow statement. The special cash flow statement following the direct method enhances the firm's ability to forecast data on its business performance as well as future cash flows.

However, based on the survey results of Tantatape, Strupeck and Whitten (2004), most of the executives, chief financial officers or managers of firms prefer to prepare the cash flow statement with the indirect method. The authors' survey found that $82 \%$ of managers prefer the indirect method, only $18 \%$ of managers prefer the direct method. The reason given by the managers supporting the indirect method is that they feel familiar with the presentation and can recognize the difference between profit and cash flow because of the simplicity and familiarity from profit and, most importantly, it is less expensive to make it. Many firms see the benefits of the direct method, but for most firms, they want to reduce the costs they have to spend if the indirect method is allowed by the authorities. In addition, according to Nurnberg (1996), the indirect method of presenting cash flow statement is useful in providing special information in the corporate's bad debts while the direct method of presenting cash flow statement cannot provide this information.

\subsection{Influence of the Method of Presenting Cash Flow Statements}

According to Le (2013), Nguyen (2015), Banna, Ahmad and Koh (2017), Nguyen and Lien (2019), to develop the economy, banks play an important role in bringing stability and development through mobilizing financial resources throughout the whole economy. The banks' lending 
performance is very much related to the use of financial statements, including cash flow statements. Surveys have been applied to assess the impact of the method of presenting cash flow statement to the decision of users of information. A research made by Klammer and Reed (1990) on 151 credit officers at US banks has shown that the direct method helps decision-makers to be more confident in their individual decision. Clinch, Dishu and Sin (2002) conducted a survey with credit officers and financial analysts to examine the correlation between financial information in economic decision presentation. They found that both target groups assessed the cash flow statement and other financial statements to be highly correlated when presenting economic decision. They pointed out that cash flow statements would complement or compensate for financial information.

Sharing this opinion, Kwok (2002), Nguyen and Tran (2014) also found that the majority of survey participants favored the direct method for decision-making. The analysis finds it more difficult to make decision when the firms present cash flow statements using the indirect method. However, Kojima (2012) believe that the indirect method is related to the profit from the income statement. Therefore, for users of information, presenting cash flow statement in the direct method will reduce the effectiveness of information provided from the income statement, which also negatively affects the decisions of information users, reducing the alignment of financial statements in making decisions. These studies conclude that the statement of cash flows should be prepared using the direct method.

According to Zhao (2013), there is not a lot of research that provides sufficient empirical evidence that information in the direct method is useful for cash flow forecasting analysts or decision-making of information users. The reason is that most firms in the countries provide information in the indirect method. Many studies do not have the size of samples needed to perform model testing. Only $4-6 \%$ of firms listed on stock exchanges make cash flow statement in the direct method. According to Nguyen and Nguyen (2020); Nguyen, Pham and Nguyen (2020), there are many factors affecting the assessment of whether firms are operating effectively, such as measurement with return on equity (ROE), return on assets (ROA), earnings per share (EPS), and cash flow of the firms. The cash flow of a firm has an important meaning besides its profit. When the cash flow of a business is good, it will bring great confidence to business managers as well as information users. According to Nguyen and Nguyen (2020), cash flow statements affect information users' decisions when corporate profit decreases. Cash flow statements also affect the comfort and confidence of information users in their decision-making. The research recognizes the role of cash flow statements, but has not yet assessed whether the method of presenting cash flow statements will affect the calculation of business targets and decisions.
Thus, the methods of presenting cash flow statement should be investigated to see which method can help users to calculate the targets of loan usage accurately. In addition, how the method of presenting cash flow statements affects lending decisions is poorly researched, especially in developing countries like Vietnam. Therefore, how the methods of presenting cash flow statements affect lending decision, and which method makes the calculation of targets performed more accurately need to be researched.

\section{Hypotheses, Data and Research Methods}

\subsection{Research Hypotheses}

To compare the loan decision by credit officers, the author conducted T-tests. The test is done to compare the decision of the credit officers on two sides: calculating the criteria supporting loan decisions and making loan decisions when the method of presenting cash flow statements is implemented in the direct method and indirect method. The first hypothesis relates to the accurate calculation of indicators related to lending activities based on cash flow statements:

H1: There is no difference in the accurate calculation of loan service criteria for bank credit officers when a cash flow statement is made either by the direct method or the indirect method.

The second hypothesis regards whether the lender's decision is influenced by the method of presenting cash flow statement.

H2: There is no difference in the loan decision of bank credit officers when the cash flow statement is made by either the direct method or the indirect method.

To do this, T-tests perform comparisons through two surveys of one firm. The first survey presents financial statements of the firm: statement of financial position, income statement, and cash flow statement in the direct method. The second survey, at the same firm, presents information on statement of financial position, income statements, and cash flow statement made in the indirect method.

\subsection{Data Collection}

Questionnaires were collected from bank staff at some joint stock commercial banks of Vietnam - Joint stock Commercial Bank for Investment and Development of Viet Nam (BIDV), Joint Stock Commercial Bank for Foreign Trade of Vietnam (Vietcombank), and Vietnam Technology and Commercial Joint Stock Bank (Techcombank). The 
author sent 130 survey worksheets of the first questionnaire and 135 survey worksheets of the second questionnaire, but the author only collected 75 survey worksheets of the first questionnaire and 75 survey worksheets of the second questionnaire.

Of the total 150 respondents, the largest age group (58\%) was $26-35$ years old, $18 \%$ were between 36 and 45 years od, and $24 \%$ were under 26 years old. Male respondents accounted for $62 \%$ of the survey and female respondents $38 \%$. The majority of the respondents had a Bachelor's degrees $(58 \%), 26 \%$ had a higher level of education, and $16 \%$ had Associate degrees. Credit officers who have worked for three years or more accounted for $72 \%$ of respondents. Credit officers are mostly experienced people who have organized or have advised on loans to firms.

\subsection{Research Methods}

The author conducted the survey of credit officers through the two questionnaires. The two questionaires provide information from the same firm with the financial statement, income statements and cash flow statement with the difference being a cash flow statement presented in the direct method and a cash flow statement presented in the indirect method. The firm is in business that has experienced profit growth through the reported two years.

The first questions regarded the assessment of loanrelated indicators calculated from cash flow statements and other financial statements. The required criteria calculated here are the inventory turnover ratio on the basis of money, unanticipated cash collection, labor intensity ratio on the basis of money, and total fixed payments

These are indicators related to cash flow statements which are usually calculated to grant loans by credit officers. Each question will be assessed as a percentage of correct answers and will be added to see how many questions the respondents answered correctly. So, the total number of correct answers will spread over five cases, from 0 to 4 , with 0 is not answering any question correctly and 4 is answering 4 questions correctly. T-tests check whether there is a difference between two survey subjects, whether the use of cash flow statements in different methods affects the calculation of indicators related to the cash flow statement.

The next question is assessed by how likely credit officers are willing to lend to the firms. The loan amount is VND5 billion. The level of consent is rated on a 5-point Likert scale, with 1 'strongly disagree' to 5 b'strongly agree'. The T-tests is also intended to find out whether the method of presenting a cash flow statement using the direct and indirect method affects the loan decision.

The final questions related to the respondents' views of of the difficulty level of this experiment assessed on a 5-point Likert scale. These questions are often used to check the interest and understanding of the survey subjects.

1. The cash flow from operating activities is clearly presented and easy to understand.

2. The language used in the cash flow statement is too complex.

3. The cash flow from operating activities is presented with sufficient information.

4. The cash flow statement helps to see the relationship with other financial statements.

5. The cash flow from operating activities clearly shows the main cash inflows and out flows activities of the firm.

In addition, these five questions also show the lenders' point of view on the method of presenting cash flow statements in terms of clarity, information provision, and relation of cash flow statement with the income statement and the statement of financial position as well as the main revenue and expenditure items of the firm. The questions raised help to have a more comprehensive view on the method of presenting cash flow statement in the direct method and indirect method.

\section{Results and Discussion}

First, let's look at the number of correct answers about the calculation of indicators related to direct and indirect methods. The proportion of bank credit staff who answered correctly is not high, especially with the indirect method. Having to answer the questions in a calculated format is not easy, even for experienced bank credit staff. The results are shown in Table 1.

When carrying out evaluation and assessment related to the number of correct answers, the results are shown in Table 2. The mean point for answering the correct questions for the indirect method is 1.8 and for the direct method is 2.61. Before performing the mean value test, we need to test two equal variances through Levene's test. The results is $0.186>0.005$, the two variances are equal, so we use the T-test result in the line of Equal variances assumed.

Table 1: Correct answer rates of lending operation questions related to cash flow statement.

\begin{tabular}{|l|c|c|}
\hline \multicolumn{1}{|c|}{ Questions about } & $\begin{array}{c}\text { Indirect } \\
\text { method }\end{array}$ & $\begin{array}{c}\text { Direct } \\
\text { method }\end{array}$ \\
\hline 1. Inventory turnover ratio & $40 \%$ & $61 \%$ \\
\hline $\begin{array}{l}\text { 2. Unanticipated Cash } \\
\text { Collection }\end{array}$ & $51 \%$ & $63 \%$ \\
\hline 3. Labor Intensity Ratio & $56 \%$ & $73 \%$ \\
\hline 4. Total Fixed Payments & $33 \%$ & $64 \%$ \\
\hline Mean point & 1.8 & 2.61 \\
\hline
\end{tabular}


We have sig $=0.000<0.05$. Therefore, we have a basis to confirm that there is a difference in calculating the lending indicators related to the method of presenting cash flow statement. Hypothesis $\mathrm{H} 1$ is rejected, the direct method of presenting cash flow statements helps credit officers calculate the targets more accurately (see Table 2).

Next, we examine the loan decision in both direct method and indirect method.

First, we test the variance of the two populations through the test of Levene' test, we have sig $=0.171>0.05$, so there is no difference in the variance of the two populations, we use the T-test result in the line of Equal variances assumed.

We have sig $=0.205>0.05$, so we have no basis to confirm that there is a difference in the loan decision regarding the method of presenting cash flow statement. The hypothesis $\mathrm{H} 2$ is not rejected, the direct method of presenting cash flow statements does not affect the loan decisions of credit officers compared to the indirect method. Some participants argued that they did not feel strange about the financial ratios in the test, however, they found it is not easy to relate the financial ratios to the loan amount (if any) that they decided to lend. The testing results are shown in Table 3 .

The evaluation of cash flow statements in the direct method and indirect method on other factors is shown in Table 4.

The author finds that the results of the comparison are statistically significant with indication of the revenue and expenditure activities of the unit and the connection with the financial statements. The results are shown in Table 5. For the comparison of revenue and expenditure activities of the unit, the mean point of the direct method is 3.72 , while the mean point of the indirect method is 2.15 . The mean point of the evaluation between the direct method and indirect method has large distance. This observation has a significance level of $0.000<0.05$. Thus, there is a basis to believe that the cash flow of the direct method helps information users to see more clearly than the indirect method.

Looking at connection with financial statements. The indirect method has more advantages than the direct method when comparing the connection with other financial statements, in particular, income statements. The mean point of the indirect method in recognizing the connection with the financial statements is 3.55 , while the mean point in the direct method is only 2.93. Sig of this comparison is 0.000 $<0.05$, so it is reasonable to assert that credit officers see the connection with other financial statements in the indirect method better. The results are shown in Table 6 .

\section{Recommendations and Conclusion}

\subsection{Recommendations}

The credit officers who receive the cash flow statement in the direct method to calculate the lending criteria, give more accurate results than the credit officers using the cash flow statement in the indirect method. The correct answer rate of the credit officers about the indirect method does not reach the average level even though these are experienced staff in lending activities.

Table 2: Compare the number of correct answers

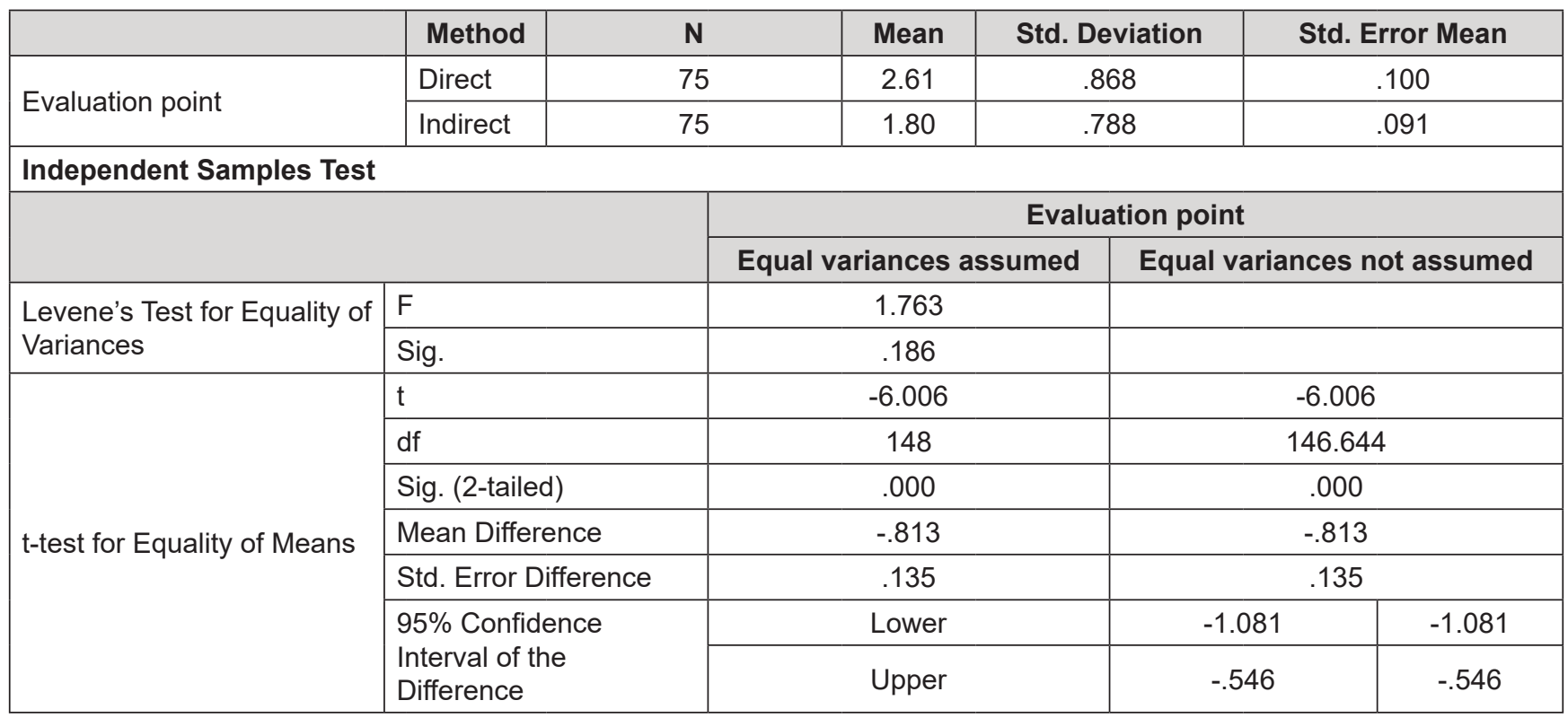


Table 3: Assessing loan decisions of credit officers

\begin{tabular}{|l|l|l|l|l|c|}
\hline \multicolumn{9}{|c|}{ Group Statistics } \\
\hline & Group & $\mathrm{N}$ & Mean & Std. Deviation & Std. Error Mean \\
\hline \multirow{2}{*}{ Evaluation point } & Direct & 75 & 2.81 & .562 & .065 \\
\cline { 2 - 7 } & Indirect & 75 & 2.69 & .592 & .068 \\
\hline
\end{tabular}

Independent Samples Test

\begin{tabular}{|c|c|c|c|c|}
\hline & & \multicolumn{3}{|c|}{ Evaluation point } \\
\hline & & Equal v & assumed & Equal variances not assumed \\
\hline \multirow{2}{*}{$\begin{array}{l}\text { Levene's Test for Equality of } \\
\text { Variances }\end{array}$} & $\mathrm{F}$ & \multicolumn{2}{|c|}{1.889} & \\
\hline & Sig. & \multicolumn{2}{|c|}{.171} & \\
\hline \multirow{7}{*}{ t-test for Equality of Means } & $\mathrm{t}$ & \multicolumn{2}{|c|}{-1.273} & -1.273 \\
\hline & df & \multicolumn{2}{|c|}{148} & 147.603 \\
\hline & Sig. (2-tailed) & \multicolumn{2}{|c|}{.205} & .205 \\
\hline & Mean Difference & \multicolumn{2}{|c|}{-.120} & -.120 \\
\hline & Std. Error Difference & \multicolumn{2}{|c|}{.094} & .094 \\
\hline & \multirow{2}{*}{$\begin{array}{l}95 \% \text { Confidence Interval } \\
\text { of the Difference }\end{array}$} & Lower & -.306 & -.306 \\
\hline & & Upper & .066 & .066 \\
\hline
\end{tabular}

Table 4: Comparison of the methods of presenting cash flow statements

\begin{tabular}{|l|c|c|}
\hline \multicolumn{1}{|c|}{ Criteria } & \multicolumn{2}{c|}{ Methods } \\
\cline { 2 - 3 } & Direct method & Indirect method \\
\hline 1. The cash flow from operating activities is clearly presented and easy to understand. & 3.31 & 3.18 \\
\hline 2. The language used in the cash flow statement is too complex. & 2.80 & 2.74 \\
\hline 3 The cash flow from operating activities is presented with sufficient information. & 3.38 & 3.18 \\
\hline $\begin{array}{l}\text { 4. The cash flow statement helps to see the relationship with other financial } \\
\text { statements. }\end{array}$ & 2.93 \\
\hline $\begin{array}{l}\text { 5. The cash flow from operating activities clearly shows the main cash inflows and } \\
\text { outflows activities of the firm. }\end{array}$ & 3.55 \\
\hline
\end{tabular}

However, the method of presenting cash flow statement does not affect the information users in making loan decisions. When making a loan decision, lenders need to use and consider many factors, so the method of presenting a cash flow statement does not affect their loan decision. However, credit officers assess the ability to view cash flow from cash flow statements in the direct method to be better. This is also the purpose of presenting cash flow statement according to international accounting standards on cash flow statements.

\subsection{Conclusion}

Currently, most companies use the indirect method to make cash flow statements, a method that helps accounting professionals to adjust information for their own purposes.
Moreover, firms are allowed to choose the method of presenting cash flow statement, so it is difficult to compare information of the firms about the ability to generate money or the efficiency of using cash flow. The proportion of firms using the indirect method has continuously decreased in recent years and is expected to continue to decrease if the firms continue to have a chance to choose the method of presenting cash flow statement.

Through the survey results, we see the direct method helps lenders to calculate the loan-related criteria more accurately than the indirect method. From the lenders' point of view, the direct method is more efficient than the indirect method in recognizing cash flow of firms, which is also the main purpose when preparing and using cash flow statement. Therefore, the author recommends that firms should make cash flow statement using the direct method. 
Table 5: Comparison of easy to identify major operating cash inflows and outflows

\begin{tabular}{|c|c|c|c|c|c|c|}
\hline \multicolumn{7}{|c|}{ Group Statistics } \\
\hline & Group & $\mathbf{N}$ & Mean & \multicolumn{2}{|c|}{ Std. Deviation } & $\begin{array}{l}\text { Std. Error } \\
\text { Mean }\end{array}$ \\
\hline \multirow{2}{*}{ Evaluation point } & Direct & 75 & 3.72 & \multicolumn{2}{|c|}{.781} & .090 \\
\hline & Indirect & 75 & 2.15 & \multicolumn{2}{|c|}{.651} & .075 \\
\hline \multicolumn{7}{|l|}{ Independent Samples Test } \\
\hline & & & \multicolumn{4}{|c|}{ Evaluation point } \\
\hline & & & \multicolumn{2}{|c|}{$\begin{array}{l}\text { Equal variances } \\
\text { assumed }\end{array}$} & \multicolumn{2}{|c|}{$\begin{array}{l}\text { Equal variances not } \\
\text { assumed }\end{array}$} \\
\hline \multirow{2}{*}{$\begin{array}{l}\text { Levene's Test for Equality of } \\
\text { Variances }\end{array}$} & \multicolumn{2}{|l|}{$\mathrm{F}$} & \multicolumn{2}{|c|}{7.690} & & \\
\hline & \multicolumn{2}{|l|}{ Sig. } & \multicolumn{2}{|c|}{.006} & \multicolumn{2}{|c|}{ 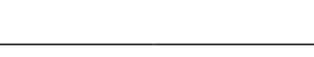 } \\
\hline \multirow{7}{*}{ t-test for Equality of Means } & \multicolumn{2}{|l|}{$\mathrm{t}$} & \multicolumn{2}{|c|}{-13.400} & \multicolumn{2}{|c|}{-13.400} \\
\hline & \multicolumn{2}{|l|}{ df } & \multicolumn{2}{|c|}{148} & \multicolumn{2}{|c|}{143.380} \\
\hline & \multicolumn{2}{|c|}{ Sig. (2-tailed) } & \multicolumn{2}{|c|}{.000} & \multicolumn{2}{|c|}{.000} \\
\hline & \multicolumn{2}{|c|}{ Mean Difference } & \multicolumn{2}{|c|}{-1.573} & \multicolumn{2}{|c|}{-1.573} \\
\hline & \multicolumn{2}{|c|}{ Std. Error Difference } & \multicolumn{2}{|c|}{.117} & \multicolumn{2}{|c|}{.117} \\
\hline & \multirow{2}{*}{\multicolumn{2}{|c|}{$\begin{array}{l}95 \% \text { Confidence Interval of the } \\
\text { Difference }\end{array}$}} & Lower & -1.805 & & \\
\hline & & & Upper & -1.341 & & \\
\hline
\end{tabular}

Table 6: Comparison of information connectivity with other financial statements in the two methods.

\begin{tabular}{|c|c|c|c|c|c|c|c|}
\hline \multicolumn{8}{|c|}{ Group Statistics } \\
\hline & Group & $\mathbf{N}$ & Mean & \multicolumn{2}{|c|}{ Std. Deviation } & \multicolumn{2}{|c|}{ Std. Error Mean } \\
\hline \multirow{2}{*}{ Evaluation point } & Direct & 75 & 2.93 & \multicolumn{2}{|c|}{.622} & \multicolumn{2}{|c|}{.072} \\
\hline & Indirect & 75 & 3.55 & \multicolumn{2}{|c|}{.934} & \multicolumn{2}{|c|}{.108} \\
\hline \multicolumn{8}{|l|}{ Independent Samples Test } \\
\hline & & & \multicolumn{5}{|c|}{ Evaluation point } \\
\hline & & & \multicolumn{2}{|c|}{$\begin{array}{l}\text { Equal variances } \\
\text { assumed }\end{array}$} & \multicolumn{3}{|c|}{$\begin{array}{l}\text { Equal variances not } \\
\text { assumed }\end{array}$} \\
\hline \multirow{2}{*}{$\begin{array}{l}\text { Levene's Test for Equality of } \\
\text { Variances }\end{array}$} & \multicolumn{2}{|l|}{$\mathrm{F}$} & \multicolumn{2}{|c|}{28.901} & & & \\
\hline & \multicolumn{2}{|l|}{ Sig. } & \multicolumn{2}{|l|}{.000} & & & \\
\hline \multirow{7}{*}{ t-test for Equality of Means } & \multicolumn{2}{|l|}{$\mathrm{t}$} & \multicolumn{2}{|l|}{4.732} & \multicolumn{3}{|c|}{4.732} \\
\hline & df & & \multicolumn{2}{|l|}{148} & \multicolumn{3}{|c|}{128.878} \\
\hline & \multicolumn{2}{|c|}{ Sig. (2-tailed) } & \multicolumn{2}{|l|}{.000} & \multicolumn{3}{|c|}{.000} \\
\hline & \multicolumn{2}{|c|}{ Mean Difference } & \multicolumn{2}{|l|}{.613} & \multicolumn{3}{|c|}{.613} \\
\hline & Std. Errc & & .130 & & \multicolumn{3}{|c|}{.130} \\
\hline & \multirow{2}{*}{\multicolumn{2}{|c|}{$\begin{array}{l}95 \% \text { Confidence Interval of the } \\
\text { Difference }\end{array}$}} & \multicolumn{2}{|l|}{ Lower } & \multicolumn{2}{|c|}{.357} & .357 \\
\hline & & & \multicolumn{2}{|l|}{ Upper } & \multicolumn{2}{|c|}{.869} & .870 \\
\hline
\end{tabular}

The requirement to make cash flow statement in the direct method should be mandatory because the freedom of choice is leading most firms to make cash flow statement in the indirect method.

\section{References}

Banna, H., Ahmad, R., \& Koh, E. H. Y. (2017). Determinants of Commercial Banks' Efficiency in Banglades: Does Crisis 
Matter? Journal of Asian Finance, Economics and Business, 4(3), 19-26. http://dx.doi.org/10.13106/jafeb.2017.vol4.no3.19

Broome, O. W. (2004). Statement of Cash Flows: Time for Change!. Financial Analysts Journal, 60(2), 16-22. https://doi. org/10.2469/faj.v60.n2.2605

Consler, J., \& Lepak, G. M. (2011). Earnings per share versus cash flow per share as predictor of dividends per share. Managerial Finance, 37(5), 482-488. DOI: 10.1108/03074351111126960 .

Clinch, G., Dishu, B., \& Sin. S. (2002). The Usefulness of Direct and Indirect Cash Flow Disclosures. Review of Accounting Studies, 7(4), 383-404.

Farshadfar, S., \& Monem, R. (2013). Further Evidence on the Usefulness of Direct Method Cash Flow Components for Forecasting Future Cash Flows. The International Journal of Accounting, 48(1), 111-133. https://doi.org/10.1016/j. intacc.2012.12.001.

Klammer, T. P., \& Reed, S. A. (1990). Operating Cash Flow Formats; Does Format Influence Decisions? Journal of Accounting and Public Policy, 9(3), 217-235. https://doi.org/10.1016/02784254(90)90011-N.

Kojama, K. (2012). Decision Usefulness of Cash Flow Information Format: An Experimental Study. International review of business, 2012(12). 23-44.

Kwok, H. (2002). The effect of cash flow statement format on lenders' decisions. The International Journal of Accounting, $37(3), 347-362$.

Nguyen, D. D., \& Nguyen, V. C. (2020). The Impact of Operating Cash flow in Decision - Making of Individual Investors in Vietnam's Stock Market. Journal of Asian Finance, Economics and Business, 7(5), 19-29. https://doi.org/10.13106/jafeb.2020. vol7.no5.019.

Nguyen, D. D., \& Tran, T. T. (2014). Discussion methods of statement of cash flows in companies listed on the stock market in Vietnam. Journal of Economics and Development, 2014(II), 69-77.

Nguyen, H. A., Pham, T. H., \& Nguyen, T. H. (2020). Impact of working capital management on firm's profitability: Empirical evidence from Vietnam. Journal of Asian Finance, Economics and Business, 7(3), 115-125. https://doi.org/10.13106/ jafeb.2020.vol7.no3.115.
Nguyen, H. A., \& Nguyen, T. H. (2020). The impact of Capital Structure on firm Performance: Evidence from Vietnam. Journal of Asian Finance, Economics and Business, 7(4), 97-105. https://doi.org/10.13106/jafeb.2020.vol7.no4.97

Nguyen, H. H., \& Lien, T. T. (2019). Factors influencing family business decision for borrowing credit from commercial banks: evidence in Tra Vinh province, Viet Nam. Journal of Asian Finance, Economics and Busines, 6(2), 119-122. https://doi. org/10.13106/jafeb.2019.vol6.no2.119

Nguyen, T. M. H. (2015) Non-Performing Loans: Affecting Factor for the Sustainability of Vietnam Commercial Banks. Journal of Economics and Development, 17(1), 93-106. DOI: 10.33301/2015.17.01.06

Nurnberg, H. (1996). The bad debt provision in the indirect method cash flows statement. The CPA Journal, 1996(11), 64-67.

Miller, P. B. W., Bahnson, P. R., \& Budge, B. P. (1996). Nonarticulation in cash flow statements and implications for education, research and practice. Accounting Horizons, 10(4), $1-15$.

Miller, P. B. W., \& Bahnson, P. R. (2002). Fast track to direct cash flow reporting. Strategic Finance, 83(8), 51-57

Le, T. B. N. (2013). Banking Relationship and Bank Financing: The Case of Vietnamese Small and Medium-sized Enterprises, Journal of Economics and Development, 15(1), 74-90. DOI: 10.33301/2013.15.01.04.

Orpurt, S. F., \& Zang, Y. (2009). Do direct cash flow disclosures help predict future operating cash flows and earnings? Accounting Review, 84(3), 893-935.

Tantatape, B., Strupeck, D., \& Whitten, D. L. (2004). Examining Preferences in Cash Flow Statement Format. The CPA Journal, 74(10), 58- 60 .

Wallace, R. S. O., Choudhury, M. S. I., Pendlebury, M. (1997). Cash flow statements: An international comparison of regulatory positions. The International Journal of Accounting, 32(1), 1-22. https://doi.org/10.1016/S0020-7063(97)90002-9

Zhao, L. (2013). Does the Presentation Format of the Statement of Cash Flows Affect Analysts' Cash Flow Forecast. The Journal of International Management Studies, 8(2), 49-53. 